\title{
Isolation and characterization of a bacterium that mineralizes toluene in the absence of molecular oxygen
}

\author{
J. Dolfing *, J. Zeyer, P. Binder-Eicher, and R. P. Schwarzenbach \\ Swiss Federal Institute for Water Resources and Water Pollution Control (EAWAG/ETH), CH-6047 Kastanienbaum, Switzerland
}

Received January 14, 1990/Accepted May 21, 1990

\begin{abstract}
A bacterium tentatively identified as a Pseudomonas sp. was isolated from a laboratory aquifer column in which toluene was degraded under denitrifying conditions. The organism mineralized toluene in pure culture in the absence of molecular oxygen. In carbon balance studies using $\left[\right.$ ring-UL- ${ }^{14} \mathrm{C}$ ] toluene, more than $50 \%$ of the radioactivity was recovered as ${ }^{14} \mathrm{CO}_{2}$. Nitrate and nitrous oxide served as electron acceptors for toluene mineralization. The organism was also able to degrade $m$-xylene, benzoate, benzaldehyde, $p$-cresol, $p$-hydroxybenzaldehyde, $p$-hydroxybenzoate and cyclohexanecarboxylic acid in the absence of molecular oxygen.
\end{abstract}

Key words: Pseudomonas sp. - Toluene - Xylene Dimethylbenzene - Aromatic compounds - Denitrification - Nitrate reduction - Anaerobic degradation

\section{Introduction}

Molecular oxygen plays a dual role in the aerobic degradation of aromatic compounds such as toluene, benzoate, aniline and phenol. It is a cosubstrate in initial reactions like the oxidation of toluene to benzylalcohol and it also serves as the final electron acceptor for mineralization (Gibson and Subramanian 1984). Under anaerobic conditions, nitrate, sulfate or other reducible species can substitute for oxygen as a final electron acceptor (Zehnder and Svensson 1986; Zehnder and Stumm 1988), however, there is no evidence that they can serve as a cosubstrate for the initial reactions. Nevertheless, a series of aromatic compounds including phenol and benzoate have been shown to be degradable under anaerobic conditions. All these compounds exhibited, however, func-

* Present address: Department of Biochemistry, Groningen Biotechnology Center, Nijenborgh 16, University of Groningen, NL-9747 AG Groningen, The Netherlands

Offprint requests to: $\mathrm{J}$. Zeyer tional groups (e.g. a hydroxy or a carboxyl group) which may facilitate the initial catabolic step (Berry et al. 1987; Evans and Fuchs 1988; Young 1984)

Anaerobic mineralization of alkylated benzenes, i.e. aromatic hydrocarbons containing no activating groups, has never been clearly demonstrated in pure cultures. Evidence for the occurrence of such processes in mixed microbial cultures has been reported by various groups (Grbić-Galić and Vogel 1987; Vogel and Grbić-Galić 1986; Wilson et al. 1986). Recently, Lovley et al. (1989) reported microbial oxidation of toluene coupled to iron reduction, but the turnover was not quantified and a carbon mass balance using ${ }^{14} \mathrm{C}$-labelled substrate was not provided. In previous work, we reported the anaerobic degradation of alkylated benzenes in denitrifying laboratory aquifer columns (Kuhn et al. 1985, 1988; Zeyer et al. 1986). In this paper, we describe the isolation and characterization of a bacterium originating from these aquifer columns that is able to mineralize toluene with nitrate or nitrous oxide as electron acceptor.

\section{Materials and methods}

\section{Chemicals}

Benzene, benzaldehyde, sodium benzoate and $o$-cresol were purchased from Merck (Darmstadt, FRG). Toluene, $o-, m-, p$-xylene, $p$-cresol, $p$-hydroxybenzylalcohol, $p$-hydroxybenzaldehyde, $p$ hydroxybenzoate, benzylalcohol, cyclohexanecarboxylic acid, naphthalene, pyruvate, sodium nitrate and sodium nitrite were from Fluka AG (Buchs, Switzerland). All chemicals were of the highest available purity and used as received. [Ring-UL- $\left.{ }^{14} \mathrm{C}\right]$ toluene (specific activity, $10.9 \mathrm{mCi} / \mathrm{mmol}$ ) and (methyl $\left.{ }^{14} \mathrm{C}\right]$ toluene (specific activity, $8.6 \mathrm{mCi} / \mathrm{mmol}$ ) were purchased from Pathfinder Laboratories (St. Louis, MO, USA). [Ring-UL- $\left.{ }^{14} \mathrm{C}\right] m$-xylene (specific activity, $93 \mathrm{mCi} / \mathrm{mmol}$ ) was from Amersham International (Arlington Heights, IL, USA). The radiochemicals had purities of greater than $98 \%$ according to the supplier and were dissolved and stored in ethanol (about $50000 \mathrm{dpm}$ per $\mu \mathrm{l}$ ). $\mathrm{N}_{2}$ (purity: $>99.999 \%$ ), $\mathrm{N}_{2} \mathrm{O}$ $(>99.5 \%)$ and $\mathrm{N}_{2} \mathrm{O} / \mathrm{N}_{2}(5 / 95, \mathrm{v} / \mathrm{v},>99.5 \%)$ were from PanGas (Lucerne, Switzerland) 


\section{Media}

The basal medium had the following composition $(\mathrm{g} / \mathrm{l}): \mathrm{KH}_{2} \mathrm{PO}_{4}$ (0.33), $\mathrm{Na}_{2} \mathrm{HPO}_{4}$ (1.2), $\mathrm{NH}_{4} \mathrm{Cl}(0.11), \mathrm{MgSO}_{4} \cdot 7 \mathrm{H}_{2} \mathrm{O}(0.10)$, $\mathrm{CaCl}_{2} \cdot 2 \mathrm{H}_{2} \mathrm{O}(0.044)$ and trace elements $(1 \mathrm{ml} / \mathrm{l})$ from a solution described previously (Zeyer and Kearney 1982). The $\mathrm{pH}$ of the medium was adjusted to 7.5 with $\mathrm{NaOH}$. Oxygen was removed from the medium by boiling, and subsequent cooling under a flux of $\mathrm{N}_{2}$ (Hungate 1969). Aliquots $(30 \mathrm{ml}$ ) of medium were placed into $50 \mathrm{ml}$ serum bottles preflushed with $\mathrm{N}_{2}$, sealed with butyl rubber stoppers (Bellco Glass, Vineland, NJ, USA) and autoclaved. To avoid precipitation, $\mathrm{CaCl}_{2} \cdot 2 \mathrm{H}_{2} \mathrm{O}$ was added from a concentrated stock solution aseptically after autoclaving. Unless stated otherwise, the media were supplemented with $10 \mathrm{mM} \mathrm{NaNO}$ as the only electron acceptor and incubations were conducted with a $\mathrm{N}_{2}$-headspace. In some degradation studies, $\mathrm{NaNO}_{3}$ was replaced by $\mathrm{N}_{2} \mathrm{O}$. In these cases, the media were purged with $\mathrm{N}_{2} \mathrm{O}$ and incubated with a $\mathrm{N}_{2} \mathrm{O}$ headspace.

To exclude the involvement of traces of molecular oxygen in the degradation of toluene, experiments were performed not only in oxygen-free media but also in chemically prereduced media. In these experiments, the media were supplemented with $\mathrm{FeS}$ (prepared according to Hanert 1981) to a final concentration of $22 \mathrm{mg} / \mathrm{l}$. Resazurin, which was added as a redox indicator to these media, was decolorized within a few hours, indicating strictly anaerobic conditions (Hungate 1969). FeS was used because addition of $\mathrm{Na}_{2} \mathrm{~S}$ in concentrations sufficient to decolorize the resazurin proved to inhibit microbial growth (data not shown). Since the solubility product of FeS is $3.7 \times 10^{-19} \mathrm{~mol}^{2} / 1^{2}$ (Weast and Astle 1981), the actual concentration of dissolved sulfide in these media remained very low $\left(<10^{-9} \mathrm{M}\right)$.

In the enrichment cultures, $0.2 \mathrm{mM}$ toluene was supplied by adding aliquots from autoclaved saturated solutions of toluene in distilled water (solubility: $6 \mathrm{mM}$, Tewari et al. 1982). Sometimes, however, micelles of toluene were formed in the stock solution which precluded accurate dosage of toluene. Therefore, for pure culture experiments, toluene and $m$-xylene were added as pure liquid by microsyringe (Hamilton, Bonaduz, Switzerland) to a final concentration of 0.2 to $0.3 \mathrm{mM} .\left[{ }^{14} \mathrm{C}\right]$ Toluene and $\left[{ }^{14} \mathrm{C}\right] \mathrm{m}$-xylene dissolved in ethanol (about $50000 \mathrm{dpm} / \mu \mathrm{l}$ ) were also added by microsyringe.

\section{Isolation of strain $T$ and growth conditions}

An enrichment culture was established by inoculating oxygen-free medium (basal medium $+0.2 \mathrm{mM}$ toluene $+10 \mathrm{mM} \mathrm{NaNO}_{3}+$ $\mathrm{N}_{2}$-headspace) with effluent from an anaerobic, toluene-degrading laboratory aquifer column that had been operated for more than one year under continuous-flow conditions (Kuhn et al. 1988). The culture was incubated and aliquots were periodically transferred to fresh medium. After several transfers, the enriched culture was serially diluted into oxygen-free basal medium supplemented with $0.2 \mathrm{mM}$ toluene and $10 \mathrm{mM} \mathrm{NaNO}$. The highest dilution showing growth and toluene degradation was again serially diluted. A pure culture was then isolated from the highest dilution of this series that showed growth by repeatedly applying the agar shake culture method as described by Pfennig and Trüper (1981). Purity of cultures was checked microscopically and by plating culture samples on solid basal medium supplemented with pyruvate $(40 \mathrm{mM})$ as the only organic carbon source. These plates were incubated aerobically. The colonies that developed were uniform and consisted of one distinct morphotype, designated strain T. Single colonies could be cultured again in oxygen-free basal medium supplemented with nitrate and toluene, and they mineralized toluene.

Liquid cultures of strain $\mathrm{T}$ were always incubated at $30 \pm 1^{\circ} \mathrm{C}$ on a rotary shaker. Strain $\mathrm{T}$ was stored under aerobic conditions on agar slants (basal medium $+20 \mathrm{mM}$ pyruvate $+2 \%$ agar) at $4^{\circ} \mathrm{C}$. To maintain viability, the strain had to be restreaked every 2 to 3 weeks.
Identification and properties of strain $T$

The identification of strain $\mathrm{T}$ was performed in the laboratories of the German Collection of Microorganisms (DSM, Braunschweig, FRG). Cells of strain $T$ are gram-negative rods measuring $0.5-$ $0.7 \times 1.5-3.5 \mu \mathrm{m}$. They are yellow-pigmented, non-spore forming, motile, denitrifying, and they accumulate poly- $\beta$-hydroxybutyrate. Electron microscopy revealed the presence of one flagellum. After aerobic growth, cells are oxidase and catalase positive and arginine dihydrolase and $\beta$-galactosidase negative. These characteristics allow tentative identification of strain $\mathrm{T}$ as a Pseudomonas sp. However, the organism forms indole from tryptophan, which is atypical of the known Pseudomonas sp.

Strain $T$ is not able to utilize sulfate $(3 \mathrm{mM})$, sulfite $(3 \mathrm{mM})$, thiosulfate $(3 \mathrm{mM})$, or $\mathrm{Fe}$ (III) (added as Fe-citrate at a concentration of $15 \mathrm{mM}$ ) as electron acceptors (tested with pyruvate as electron donor). Electron donors degraded with nitrate as electron acceptor include acetate, pyruvate, fructose, and glucose. The strain, however, does not grow on ethanol. It should be noted that the growth rate of strain $T$ varied from batch to batch without apparent variation in media composition or other growth conditions. For example, the exponential growth rate on basal medium + pyruvate $+\mathrm{NaNO}_{3}+\mathrm{N}_{2}$-headspace varied between 0.06 and $0.15 \mathrm{~h}^{-1}$.

\section{Carbon balance studies using radiolabelled toluene}

Oxygen-free or chemically reduced media were supplemented with $\left[{ }^{14} \mathrm{C}\right]$ toluene and $\left[{ }^{14} \mathrm{C}\right] m$-xylene, respectively (approximately $2000-$ $5000 \mathrm{dpm} / \mathrm{ml}$ ), and inoculated with aliquots of a culture of strain $\mathrm{T}$ pregrown on oxygen-free basal medium plus $10 \mathrm{mM}$ nitrate plus $5 \mathrm{mM}$ pyruvate. Non-inoculated media served as controls. At the end of the incubation (usually 2 weeks), the cultures were acidified to a $\mathrm{pH}$ of about 2 with $\mathrm{HCl}$, and subsequently purged with air. The air was passed through two traps, each containing $20 \mathrm{ml}$ of isobutanol (to trap any remaining toluene, $m$-xylene or other volatile organic compounds), and through two traps each containing $20 \mathrm{ml}$ of $0.1 \mathrm{~N} \mathrm{NaOH}$ (to absorb $\mathrm{CO}_{2}$ ). After purging, the radioactivity in the traps and the radioactivity remaining in the acidified culture was quantitified. To recover and quantify sorbed $\left[{ }^{14} \mathrm{C}\right]$ toluene, the butyl rubber stoppers were extracted overnight with ethyl acetate. Quantification of ${ }^{14} \mathrm{C}$ was performed by adding $1 \mathrm{ml}$-samples of isobutanol, $\mathrm{NaOH}$ solution, ethyl acetate and culture fluid, respectively, to $10 \mathrm{ml}$ of Kontrogel (Kontron, Zürich, Switzerland) and subsequent counting in a Tri-Carb liquid scintillation counter (Packard, Downers Grove, IL, USA).

\section{Determination of growth and analytical methods}

Growth was measured by determining the optical density of cultures at $546 \mathrm{~nm}\left(\mathrm{OD}_{546}\right)$ with a Uvikon 810 spectrophotometer (Kontron, Zürich, Switzerland). To study growth-inhibitory effects of certain compounds (e.g. nitrite or suspected intermediates of toluene degradation) on strain $T$, the organism was grown on basal medium $+40 \mathrm{mM}$ pyruvate in the presence of $\mathrm{N}_{2} \mathrm{O}$ as sole electron acceptor in a $50 \mathrm{ml}$ serum bottle. At the beginning of the exponential growth phase, the test compound was added from a concentrated aqueous stock solution. The exponential growth rate of the spiked culture was then compared to the growth rate of an unspiked culture.

Concentrations of aromatic substrates and of cyclohexanecarboxylic acid were assayed by gas chromatography or high-pressure liquid chromatography as described previously (Kuhn et al. 1988). Pyruvate was quantified enzymatically with a lactate dehydrogenase assay (Sigma Diagnostics, St. Louis, USA). Nitrate was determined by a salicylate based colorimetric method (Legler 1971) and nitrite by a diazotization-based colorimetric method (Montgomery and Dymock 1961). 
Table 1. Degradation of $\left[{ }^{14} \mathrm{C}\right]$ toluene by strain $\mathrm{T}$ with nitrate as sole electron acceptor. The data represent average values of at least two independent determinations. Media and analytical procedures are described in Methods

\begin{tabular}{|c|c|c|c|c|c|}
\hline \multirow{2}{*}{$\begin{array}{l}\text { Growth conditions } \\
\text { and substrate }\end{array}$} & \multicolumn{5}{|c|}{${ }^{14} \mathrm{C}$ Balance after an incubation time of 2 weeks [\%] } \\
\hline & $\begin{array}{l}{\left[{ }^{14} \mathrm{C}\right] \text { Toluene }} \\
\text { recovered from } \\
\text { culture }\end{array}$ & ${ }^{14} \mathrm{CO}_{2}$ evolved & $\begin{array}{l}{ }^{14} \mathrm{C} \text {-labeled } \\
\text { residues remaining } \\
\text { in culture }\end{array}$ & $\begin{array}{l}{\left[{ }^{14} \mathrm{C}\right] \text { Toluene sorbed: }} \\
\text { to stopper }\end{array}$ & $\begin{array}{l}\text { Total }{ }^{14} \mathrm{C} \\
\text { recovery }\end{array}$ \\
\hline $\begin{array}{l}\text { Oxygen free medium } \\
{\left[\text { Ring-UL-UL }-{ }^{14} \mathrm{C}\right] \text { toluene }} \\
{\left[\text { Methyl }-{ }^{14} \mathrm{C}\right] \text { toluene }}\end{array}$ & & $\begin{array}{l}51 \\
52\end{array}$ & $\begin{array}{r}17 \\
9\end{array}$ & $\begin{array}{l}22 \\
18\end{array}$ & $\begin{array}{l}91 \\
81\end{array}$ \\
\hline $\begin{array}{l}\text { Medium reduced with } \mathrm{FeS}^{\mathrm{b}} \\
{\left[\text { Ring-UL- }{ }^{4} \mathrm{C}\right] \text { toluene }}\end{array}$ & $<1$ & 51 & 24 & 9 & $>84$ \\
\hline $\begin{array}{l}\text { Sterile control }{ }^{\mathrm{a}} \\
\quad\left[\text { Ring-UL- }{ }^{14} \mathrm{C}\right] \text { toluene }\end{array}$ & 13 & $<1$ & $<1$ & 69 & 83 \\
\hline
\end{tabular}

\section{Results and discussion}

\section{Degradation of toluene by strain $T$}

Strain $\mathrm{T}$ was able to mineralize toluene in an oxygenfree medium supplemented with nitrate as sole electron acceptor. A carbon mass balance was established using $\left[{ }^{14} \mathrm{C}\right]$ toluene as substrate (Table 1). After a 2-week incubation, $2 \%$ of the applied radioactivity was recovered as non-degraded toluene, and more than $50 \%$ was evolved as ${ }^{14} \mathrm{CO}_{2}$. Up to $17 \%$ remained in the culture as ${ }^{14} \mathrm{C}$ labeled non-volatile residues. Analysis of these residues by high-pressure liquid chromatography did not reveal any identifiable metabolites. Mineralization of toluene took also place in cultures growing on chemically reduced medium (Table 1) which demonstrates that molecular oxygen is not involved in the degradation of toluene. At the beginning of the incubation, a large part (usually two thirds) of the applied toluene was sorbed by the butyl rubber stoppers. This sorption process was largely reversible and equilibrium conditions were established within a few hours. During incubation with strain $\mathrm{T}$, toluene was slowly desorbed and converted to $\mathrm{CO}_{2}$. At the end of the incubation, the amount of toluene extractable from the butyl rubber stoppers was below $22 \%$ in all cultures (Table 1). Only in the sterile control was a large part of toluene associated with the stopper. It is possible that the poor overall recovery of radioactivity $(81-91 \%)$ in the cultures is due to an incomplete desorption and extraction of toluene from the butyl rubber stoppers.

\section{Substrate specificity of strain $T$}

In addition to toluene, strain $T$ was also able to mineralize $m$-xylene in the presence of nitrate. A carbon balance study using $0.3 \mathrm{mM}$ [ring-UL- $\left.{ }^{14} \mathrm{C}\right] m$-xylene as sole source of energy and $10 \mathrm{mM}$ nitrate as sole electron acceptor revealed that more than $50 \%$ of the radioactivity was evolved as ${ }^{14} \mathrm{CO}_{2}$ within 16 days. Strain $\mathrm{T}$, however, was unable to degrade $o$-xylene, $p$-xylene, benzene or naphthalene in the absence of molecular oxygen. It is noteworthy that the laboratory aquifer column from which strain $\mathrm{T}$ was isolated initially degraded $m$-xylene and p-xylene, in the presence of nitrate (Kuhn et al. 1985). Upon extended enrichment with $m$-xylene, the microbial population in the column lost the ability to degrade $p$ xylene in the absence of molecular oxygen (Zeyer et al. 1986; Kuhn et al. 1988).

The pathway of toluene degradation in the absence of molecular oxygen is unknown. Vogel and Grbić-Galić (1986) suggested a transformation of toluene to $p$-cresol which can be converted to $p$-hydroxybenzoate and benzoate under anaerobic conditions (Evans and Fuchs 1988; Bossert and Young 1986; Taylor et al. 1970). Alternatively, degradation of toluene through benzyl alcohol and benzaldehyde to benzoate is very common under aerobic conditions (Gibson and Subramanian 1984), but there is only very weak evidence for the occurrence of such a pathway in the absence of molecular oxygen (Grbić-Galic and Vogel 1987). The anaerobic mineralization of benzoate (e.g. through cyclohexanecarboxylic acid) is well documented (Evans and Fuchs 1988; Young 1984). The most intriguing question about the anaerobic toluene degradation is the mechanism of the initial catabolic step, i.e. the activation of the toluene molecule in the absence of molecular oxygen.

Based on literature data and results from studies with a laboratory aquifer column, we postulated a number of hypothetical intermediates of anaerobic toluene degradation (Kuhn et al. 1988). As a follow-up to these suggestions, we determined whether strain $\mathrm{T}$ was able to grow on these compounds using nitrate as sole electron acceptor (Table 2). To avoid toxic effects of these hypothetical intermediates on strain $\mathrm{T}$, the growth studies were performed at substrate concentrations of $1 \mathrm{mM}$. Benzaldehyde exhibited a severe growth-inhibitory effect on strain $\mathrm{T}(90 \%$ growth inhibition at a concentration of $2 \mathrm{mM}$, Table 2) and therefore this substrate was provided at a concentration of $0.5 \mathrm{mM}$. Among the substrates tested, only benzylalcohol and $o$-cresol did not serve as growth substrates for strain $\mathrm{T}$. Therefore the pattern of compounds degradable by strain $\mathrm{T}$ does not suggest a particular pathway for anaerobic toluene metabolism. 
Table 2. Degradation of various substrates by strain $T$

\begin{tabular}{llll}
\hline Substrate & $\begin{array}{l}\text { Growth } \\
\text { inhibition } \\
\text { by substrate } \\
{[\%]^{\mathrm{a}}}\end{array}$ & $\begin{array}{l}\text { Growth } \\
\text { on } \\
\text { substrate }\end{array}$ & $\begin{array}{l}\text { Substrate } \\
\text { recovered } \\
\text { after growth } \\
{[\% \text { of initial] }}\end{array}$ \\
\cline { 2 - 3 } $\begin{array}{lll}p \text {-Cresol } \\
p \text {-Hydroxybenzyl- }\end{array}$ & 28 & & $<1$ \\
$\quad$ alcohol & 86 & + & $<1$ \\
$p$-Hydroxybenzaldehyde & 28 & + & $<1$ \\
$p$-Hydroxybenzoate & 26 & + & $<1$ \\
$a$-Cresol & 43 & - & $>95$ \\
$\begin{array}{l}\text { Benzylalcohol } \\
\text { Benzaldehyde }\end{array}$ & 39 & - & $>95$ \\
Benzoate & 90 & + & $<1$ \\
Cyclohexanecarboxylic & 26 & & $<1$ \\
$\quad$ acid & 26 & & \\
\hline
\end{tabular}

${ }^{a}$ Growth inhibition was measured as described in Methods (substrate concentration: $2 \mathrm{mM}$ )

${ }^{\mathrm{b}}$ Growth was determined on basal medium $+1 \mathrm{mM}$ substrate (for benzaldehyde: $0.5 \mathrm{mM}$ only) $+10 \mathrm{mM}$ nitrate $+\mathrm{N}_{2}$-headspace. $(+)$ significant turbidity. $(-)$ no growth

Moreover, these data have to be interpreted with great caution because growth studies may be impeded both by uptake and induction effects. Tschech and Fuchs (1987) recently reported the isolation of a phenol-degrading denitrifying Pseudomonas sp. which grew on most of the hypothetical intermediates tested in Table 2, but which was unable to degrade toluene.

\section{Electron acceptors used by strain $T$}

The toluene-degrading laboratory aquifer columns from which strain $T$ was isolated reduced nitrate and accumulated nitrite. Only a fraction of the nitrite was further reduced to gaseous nitrogen species (Zeyer et al. 1986). The reduction of nitrate to nitrite in the presence of a degradable carbon source (e.g. toluene or pyruvate) could also be demonstrated in a pure culture of strain $T$. The strain was grown on $2 \mathrm{mM}$ pyruvate in the presence of $10 \mathrm{mM}$ nitrate as sole electron acceptor (Fig. 1). After a lag phase of about $4 \mathrm{~h}$, pyruvate was degraded at an apparently constant rate of $0.3 \mathrm{mM} / \mathrm{h}$ and this oxidation was coupled to a reduction of nitrate to nitrite at a rate of about $0.5 \mathrm{mM} / \mathrm{h}$. Nitrite reduction only started after a lag phase of several days. Further experiments confirmed that cells of strain $T$ which were pregrown in the presence of nitrate were able to resume growth in the presence of nitrite only after an adaption period of several days. Similarly, in the laboratory aquifer column from which strain $\mathrm{T}$ was isolated, toluene degradation was severely reduced upon replacement of nitrate by nitrite (Kuhn et al. 1988). It is noteworthy that two Pseudomonas sp. able to grow with nitrate on phenol or anthranilic acid, respectively, showed a behaviour similar to strain $T$, i.e. nitrite was stoichiometrically accumulated and further reduced only after nitrate depletion (Tschech and Fuchs 1987; Braun and Gibson 1984). In addition, Körner and Zumft (1989) demonstrated that reduction of nitrite to

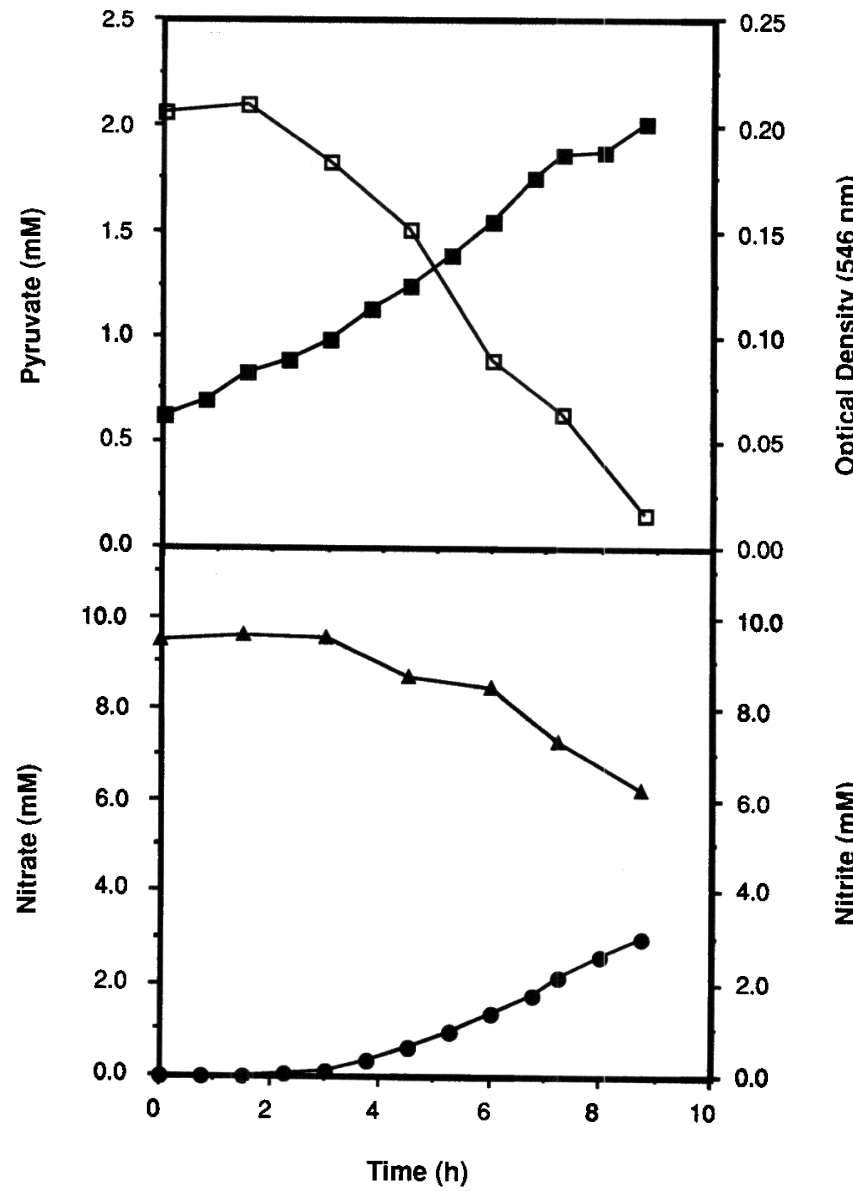

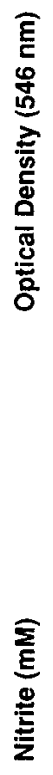

Fig. 1. Coupling of pyruvate oxidation with nitrate reduction. Strain $T$ was grown on basal medium $+2 \mathrm{mM}$ pyruvate $+10 \mathrm{mM}$ nitrate $+\mathrm{N}_{2}$-headspace. Samples were periodically withdrawn and analyzed for $\square$ turbidity, $\square$ pyruvate, $\boldsymbol{\Delta}$ nitrate and $\boldsymbol{D}$ nitrite

molecular nitrogen by a Pseudomonas stutzeri was completely inhibited in the presence of nitrate even though the nitrite reductase was induced.

Nitrite exhibited a severe growth-inhibitory effect on strain T. Addition of $5 \mathrm{mM}$ nitrite to a growing culture of strain $\mathrm{T}$ reduced the exponential growth rate by $50 \%$ and addition of $10 \mathrm{mM}$ nitrite inhibited growth totally. A slow adaption was recognizable only after several hours. Theoretically, total oxidation of $1 \mathrm{mM}$ toluene $\left(\mathrm{C}_{7} \mathrm{H}_{8}\right)$ to $7 \mathrm{mM} \mathrm{CO}_{2}$ and $4 \mathrm{mM} \mathrm{H}_{2} \mathrm{O}$ must be coupled to the reduction of $18 \mathrm{mM}$ nitrate to nitrite. Since up to $0.3 \mathrm{mM}$ toluene was routinely used in the previous degradation studies and more than $50 \%$ was mineralized to $\mathrm{CO}_{2}$ (Table 1), an accumulation of about $3 \mathrm{mM}$ nitrite and hence a growth-inhibition is expected.

Growth-inhibitory effects by accumulated nitrite, however, could be avoided by replacing nitrate with nitrous oxide. Growing on $\mathbf{4 0} \mathrm{mM}$ pyruvate, strain $\mathrm{T}$ was able to use not only nitrate but also nitrous oxide as electron acceptor (Table 3). The exponential growth rate in the presence of nitrate, $5 \%$ nitrous oxide and $100 \%$ nitrous oxide, respectively, was within a narrow range. The cell yield (expressed as $\mathrm{OD}_{546, \mathrm{max}}$ ), however, was 
Table 4. Degradation of $\left[{ }^{14} \mathrm{C}\right]$ toluene by strain $\mathrm{T}$ with nitrous oxide as sole electron acceptor. The data represent average values of at least 2 independent determinations. Media and analytical procedures are described in Methods

\begin{tabular}{|c|c|c|c|c|c|}
\hline \multirow{2}{*}{$\begin{array}{l}\text { Growth conditions } \\
\text { and substrate }\end{array}$} & \multicolumn{5}{|c|}{${ }^{14} \mathrm{C}$ Balance after an incubation time of 2 weeks [\%] } \\
\hline & $\begin{array}{l}{\left[{ }^{14} \mathrm{C}\right] \text { Toluene }} \\
\text { recovered from } \\
\text { culture }\end{array}$ & ${ }^{14} \mathrm{CO}_{2}$ evolved & $\begin{array}{l}{ }^{14} \mathrm{C} \text {-labeled } \\
\text { residues remaining } \\
\text { in culture }\end{array}$ & $\begin{array}{l}{\left[{ }^{14} \mathrm{C}\right] \text { Toluene sorbed }} \\
\text { to stopper }\end{array}$ & $\begin{array}{l}\text { Total }{ }^{14} \mathrm{C} \\
\text { recovery }\end{array}$ \\
\hline \multicolumn{6}{|l|}{ Oxygen free medium ${ }^{\mathrm{a}}$} \\
\hline [Ring-UL- $\left.{ }^{14} \mathrm{C}\right]$ toluene & $<1$ & 58 & 21 & 13 & $>92$ \\
\hline$\left[\right.$ Methyl- $\left.{ }^{14} \mathrm{C}\right]$ toluene & $<1$ & 61 & 13 & 11 & $>85$ \\
\hline \multicolumn{6}{|l|}{ Medium reduced with $\mathrm{FeS}^{\mathrm{b}}$} \\
\hline$\left[\right.$ Ring-UL- $\left.{ }^{14} \mathrm{C}\right]$ toluene & 14 & & 6 & 57 & 79 \\
\hline \multicolumn{6}{|l|}{ Sterile control ${ }^{\mathrm{a}}$} \\
\hline [Ring-UL- $\left.{ }^{14} \mathrm{C}\right]$ toluene & 16 & $<1$ & $<1$ & 69 & $>85$ \\
\hline
\end{tabular}

Basal medium $+0.3 \mathrm{mM}$ toluene $+\left[{ }^{14} \mathrm{C}\right]$ toluene $(2000 \mathrm{dpm} / \mathrm{ml})+\mathrm{N}_{2} \mathrm{O}$-headspace

${ }^{b}$ As in a, but supplemented with FeS

Table 3. Growth of strain $\mathrm{T}$ in the presence of various electron acceptors. Strain T was grown on basal medium $+20 \mathrm{mM}$ pyruvate in the presence of the indicated nitrogen species as sole electron acceptor. The preculture used to inoculate the test cultures contained nitrous oxide as sole electron acceptor

\begin{tabular}{llc}
\hline Electron acceptor & $\mu\left[\mathrm{h}^{-1}\right]$ & $\mathrm{OD}_{546, \text { max }}$ \\
\hline $\mathrm{Nitrate}[10 \mathrm{mM}]$ & 0.26 & 0.8 \\
$\mathrm{~N}_{2} \mathrm{O}[100 \%]$ & 0.20 & 1.4 \\
$\mathrm{~N}_{2} \mathrm{O} / \mathrm{N}_{2}[5 / 95, \mathrm{v} / \mathrm{v}]$ & 0.28 & 1.6 \\
$\mathrm{~N}$ & - & $<0.2$
\end{tabular}

considerably lower with nitrate than with nitrous oxide. This is probably due to nitrite toxicity.

A carbon mass balance for degradation of $\left[{ }^{14} \mathrm{C}\right]$ toluene in the presence of nitrous oxide as sole electron acceptor is presented in Table 4 . Within a 2-week incubation, about $60 \%$ of the initially applied radioactivity was evolved as ${ }^{14} \mathrm{CO}_{2}$. Toluene degradation, however, was severely inhibited by FeS, which is in obvious contrast to the results listed in Table 1. This apparent contradiction is probably due to the fact that sulfide inhibits the nitrous oxide reductase but not the nitrate reductase (Sørensen et al. 1980), i.e., in the presence of sulfide, toluene oxidation cannot be coupled to nitrous oxide reduction. It is assumed that the nitrous oxide reductase requires copper as a cofactor (Knowles 1982) and this metal is probably not available in the presence of sulfide due to the low solubility produced of $\mathrm{CuS}$ $\left(8.5 \times 10^{-4,5} \mathrm{~mol}^{2} / 1^{2}\right.$, Weast and Astle 1981).

Acknowledgements. We thank R. Schocher, M. Glaus and D. Macalady for stimulating discussions and D. Studer for providing the electron micrographs. This project was supported by grants from Ciba-Geigy AG and the European Communities (Project COST 641).

\section{References}

Berry DF, Francis AJ, Bollag J-M (1987) Microbial metabolism of homocyclic and heterocyclic aromatic compounds under anaerobic conditions. Microbiol Rev 51:43-59
Bossert ID, Young LY (1986) Anaerobic oxidation of $p$-cresol by a denitrifying bacterium. Appl Environ Microbiol 52:1117-1122

Braun K, Gibson DT (1984) Anaerobic degradation of 2-aminobenzoate (anthranilic acid) by denitrifying bacteria. Appl Environ Microbiol 48:102-107

Evans WC, Fuchs G (1988) Anaerobic degradation of aromatic compounds. Annu Rev Microbiol 42:289-317

Gibson DT, Subramanian V (1984) Microbial degradation of aromatic hydrocarbons. In: Gibson DT (ed) Microbial degradation of organic compounds. Marcel Dekker, New York, pp $181-$ 252

Grbić-Galić D, Vogel TM (1987) Transformation of toluene and benzene by mixed methanogenic cultures. Appl Environ Microbiol 53:254-260

Hanert HH (1981) The genus Gallionella. In: Starr MP, Stolp H, Trüper HG, Balows A, Schlegel HG (eds) The prokaryotes. Springer, Berlin Heidelberg New York, pp 509-515

Hungate RE (1969) A roll tube method for cultivation of strict anaerobes. In: Norris JR, Ribbons DW (eds) Methods in microbiology, vol 3 B. Academic Press, New York, pp 117-132

Knowles R (1982) Denitrification. Microbiol Rev 46:43-70

Körner H, Zumft WG (1989) Expression of denitrification enzymes in response to the dissolved oxygen level and respiratory substrate in continuous culture of Pseudomonas stutzeri. Appl Environ Microbiol 55:1670-1676

Kuhn EP, Colberg PJ, Schnoor JL, Wanner O, Zehnder AJB, Schwarzenbach RP (1985) Microbial transformations of substituted benzenes during infiltration of river water to groundwater: laboratory column studies. Environ Sci Technol 19:961 -968

Kuhn EP, Zeyer J, Eicher P, Schwarzenbach RP (1988) Anaerobic degradation of alkylated benzenes in denitrifying laboratory aquifer columns. Appl Environ Microbiol 54:490-496

Legler C (1971) Ausgewählte Methoden der Wasseruntersuchung, Band I: Chemische, physikalisch-chemische, physikalische und elektrochemische Methoden. Gustav Fischer, Jena

Lovley DR, Baedecker MJ, Lonergan DJ, Cozzarelli IM, Phillips EJP, Siegel DI (1989) Oxidation of aromatic contaminants coupled to microbial iron reduction. Nature 339:297-300

Montgomery HAC, Dymock JF (1961) The determination of nitrite in water. Analyst 86:414-416

Pfennig N, Trüper HG (1981) Isolation of members of the families Chromatiacea and Chlorobiacea. In: Starr MP, Stolp H, Trüper HG, Balows A, Schlegel HG (eds) The prokaryotes. Springer, Berlin Heidelberg New York, pp 279-289

Sørensen J, Tiedje JM, Firestone RB (1980) Inhibition by sulfide of nitric and nitrous oxide reduction by denitrifying Pseudomonas fluorescens. Appl Environ Microbiol 39:105-108 
Taylor BF, Campbell WL, Chinoy I (1970) Anaerobic degradation of the benzene nucleus by a facultatively anaerobic microorganism. J Bacteriol 102:430-437

Tewari YB, Miller MM, Wasik SP, Martire DE (1982) Aqueous solubility and octanol/water partition coefficient of organic compounds at $25^{\circ} \mathrm{C}$. J Chem Eng Data 27:451 -454

Tschech A, Fuchs G (1987) Anaerobic degradation of phenol by pure cultures of newly isolated denitrifying pseudomonads. Arch Microbiol 148:213-217

Vogel TM, Grbić-Galić D (1986) Incorporation of oxygen from water into toluene and benzene during anaerobic fermentative transformation. Appl Environ Microbiol 52:200-202

Weast RC, Astle MJ (1981) Handbook of chemistry and physics. CRC Press, Boca Raton, FL

Wilson BH, Smith GB, Rees JF (1986) Biotransformations of selected alkylbenzenes and halogenated aliphatic hydrocarbons in methanogenic aquifer material: a microcosm study. Environ Sci Technol 20:997-1002
Young LY (1984) Anaerobic degradation of aromatic compounds. In: Gibson DT (ed) Microbial degradation of organic compounds. Marcel Dekker, New York, pp 487-523

Zehnder AJB, Stumm W (1988) Geochemistry and biogeochemistry of anaerobic habitats. In: Zehnder AJB (ed) Biology of anaerobic microorganisms. John Wiley \& Sons, New York, pp 1-38

Zehnder AJB, Svensson BH (1986) Life without oxygen: what can and what cannot? Experientia 42:1197-1205

Zeyer J, Kearney PC (1982) Microbial degradation of parachloroaniline as sole carbon and nitrogen source. Pestic Biochem Physiol 17:215-223

Zeyer J, Kuhn EP, Schwarzenbach RP (1986) Rapid microbial mineralization of toluene and 1,3-dimethylbenzene in the absence of molecular oxygen. Appl Environ Microbiol 52:944947 